\title{
Insect pollinator's community structure in different habitats of Shivapuri-Nagarjun National Park, Nepal
}

\author{
Urmila Dyola $^{1}$, Chitra Baniya ${ }^{2}$, Pushpa Acharya ${ }^{3}$, Pradip Subedi ${ }^{4}$, Anjeela Pandey ${ }^{1}$, and \\ Kumar Sapkota ${ }^{1}$
}

${ }^{1}$ Tribhuvan University Central Department of Zoology

${ }^{2}$ Tribhuvan University Central Department of Botany

${ }^{3}$ Mid-Western University

${ }^{4}$ Macquarie University

October 6, 2021

\begin{abstract}
Insect pollinators are important means for a stable ecosystem. The habitat types play a crucial role in the community composition, abundance, diversity, and species richness of the pollinators. The present study in Shivapuri-Nagarjun National Park explored the species richness and abundances of insect pollinators in four different habitats and different environmental variables in determining the community composition of the pollinators. Data were collected from $1500 \mathrm{~m}-2700 \mathrm{~m}$ using pan traps and hand sweeping methods. Non-metric multidimensional scaling (NMDS) and redundancy analysis (RDA) were conducted to show the association between insect pollinators and environmental variables. The results firmly demonstrated that species richness and abundances were higher in open trails compared to other habitats. The distribution of the pollinator species was more uniform in the open trail followed by the grassland. Similarly, a strong positive correlation between flower resources and pollinator's abundance was found. In conclusion, the open trail harbor rich insect pollinators in lower elevation. The community structure of the pollinators was strongly influenced by the presence of flowers in the trails.
\end{abstract}

Insect pollinator's community structure in different habitats of Shivapuri-Nagarjun National Park, Nepal

Urmila Dyola ${ }^{1,5}$, Chitra Bahadur Baniya ${ }^{2}$, Pushpa Raj Acharya ${ }^{3}$, Pradip Subedi ${ }^{4}$, Anjeela Pandey ${ }^{1}$, Kumar Sapkota 1,5

${ }^{1}$ Central Department of Zoology, Tribhuvan University, Kirtipur, Kathmandu, Nepal

${ }^{2}$ Central Department of Botany, Tribhuvan University, Kirtipur, Kathmandu, Nepal

${ }^{3}$ Mid-Western University, Surkhet, Nepal

4 Department of Biological Sciences, Macquarie University, North Ryde, NSW, Australia

${ }^{5}$ Corresponding authors. E- mail:

dyolaurmila@gmail.com,ksapkota.cdztu@cdz.tu.edu.np

\section{Abstract}

Insect pollinators are important means for a stable ecosystem. The habitat types play a crucial role in the community composition, abundance, diversity, and species richness of the pollinators. The present study in Shivapuri-Nagarjun National Park explored the species richness and abundances of insect pollinators in 
four different habitats and different environmental variables in determining the community composition of the pollinators. Data were collected from $1500 \mathrm{~m}-2700 \mathrm{~m}$ using pan traps and hand sweeping methods. Non-metric multidimensional scaling (NMDS) and redundancy analysis (RDA) were conducted to show the association between insect pollinators and environmental variables. The results firmly demonstrated that species richness and abundances were higher in open trails compared to other habitats. The distribution of the pollinator species was more uniform in the open trail followed by the grassland. Similarly, a strong positive correlation between flower resources and pollinator's abundance was found. In conclusion, the open trail harbor rich insect pollinators in lower elevation. The community structure of the pollinators was strongly influenced by the presence of flowers in the trails.

KEYWORDS Community composition; Open trail; Pollinators; Shivapuri-Nagarjun National Park; Species richness

\section{INTRODUCTION}

Pollinators are important agents for a stable ecosystem (Kremer, 2008; De Groot et al., 2010). They enhance pollination for both wild and flowering plants and also help humans to increase agricultural production (Kevan et al., 1990; Corbet et al., 1991; Widhiono et al., 2016). These insects also benefit the economic, aesthetic, and cultural aspects of mankind (Gill et al., 2016). In general, social and solitary bees, butterflies and moths, beetle and flies account as dominant pollinators (Vanbergen and Initiative, 2013; Wojcik, 2021).

Most of the cultivated plants around the world are pollinated by bees (56.5\%), flies (19\%) and, butterflies (4\%) (Bashir et al., 2019). Honey bees are well-known insects in comparison to wild pollen bees (Losey and Vaughan, 2006; Potts et al., 2010) while flies and butterflies are less known. (Jennersten, 1984; Larson et al., 2001). Pollinators decline is a globally recorded phenomenon (Carvalheiro et al., 2013; Dirzo et al., 2016). Especially, bumblebees (Fitzpatrick et al., 2007; Cameron et al., 2011), butterflies (Warren et al., 2001; Van Swaay et al., 2010), and honeybees (Vanengelsdrop et al., 2008) population is shrinking in the world due to natural as well anthropogenic threats. The major drivers of pollinator loss are recognized as habitat loss, landscape modification, intensification in agriculture, and even climate change (Kearns et al., 1998; Potts et al., 2010; Kovács-Hostyanszk et al., 2017). Hence, maintaining pollinator diversity in the given landscape requires an understanding of a clear pattern of pollinator diversity along with the habitat types.

The community composition of pollinators depends upon the local environment (Williams et al., 2010). The activity of pollinators is strongly correlated with air temperature; bees and butterflies prefer warmer temperatures than flies (Kuhsel \& Bluthgen, 2015), plant species richness (Hudewenz et al., 2012), and elevation; Hymenoptera is dominant pollinators in lowland while Lepidoptera and Diptera dominate at high land (Warren et al., 1988). They require a range of habitats for fulfilling their ecological requirements. However, these ecological demands for insect pollinators are mostly species or guild-specific (Proesmans et al., 2019). Bees prefer to forage the flower plants close to the nesting area (Gathmann and Tscharntke, 2002; Greenleaf et al., 2007). Hoverflies and butterflies do not construct the nest and fly away from the egg-laying areas for foraging. Aphidophagous hoverflies such as Episyrphus, Sphaerophoria depend on agricultural habitat (Jauker et al., 2009; Pinheiro et al., 2015), while saproxylic hoverflies (Xylota) are benefitted from the forest (Reemer, 2005), hence, strongly associated with them. Butterflies forage varieties of flower for nectar (Tiple et al., 2005) and can make the flight over greater distances (Herrera, 1987). Such movement may show the selection of varied nutrition of butterflies; pollen (Gilbert, 1972), tree sap, rotting fruit, and dung, decaying flesh, and dissolved minerals in wet sand or dirt. Additionally, oviposition-plant location signifies habitat selection for smaller and less mobile butterflies, such as the "blues," while the larger butterflies like Erebia epipsodea and Colias probably have fairly large ranges of the search for their widespread ovipositing plants (Sharp et al., 1974). Bee's community structure is also designated by the availability of the nesting substrates. Bee species construct the nest in deadwood (Sydenham et al., 2016) and in the soil of sun-exposed ground (Everaars et al., 2011). So, habitat sharing among the pollinators is obvious. The habitat types play a crucial role in the community composition, abundance, diversity, and species richness of flowering plants and hence the pollinators. 
Few studies were found on the study of insect pollinators in different habitats of National Park. We hypothesized that the visit of insect pollinators depends on the floral diversity found in the given habitats. The presence of these plants is strongly influenced by habitat types and elevation. The general understanding is that the natural habitat, if free from pesticides, will probably possess more diversity than the managed habitat. However, the habitat heterogeneity would also affect the pollinator community as the interaction plant-pollinator is specific (Weibull et al., 2000; Rundlof et al., 2008; Oliver et al., 2010).

Similarly, we examined species richness, abundance and, the community composition of insect pollinators in different habitats along the elevation gradient. The pollinator survey was carried at Shivapuri-National Park (SNNP) including managed habitats of buffer zone areas. The research questions were designed to find whether the pollinator composition (richness, abundance, and their association) differs from the defined habitats (grassland, managed area, open trails, and trails of forest) of SNNP. 'Is pollinator composition influenced by the elevation gradient at the landscape?'

\section{MATERIALS AND METHODS}

\subsection{Study Area}

Shivapuri-Nagarjun National Park (SNNP) (Figure 1) is the only protected area in the mid-hill region of Nepal. The Park covers an area of 159 square kilometers with a buffer area of around 118.61 square $\mathrm{km}$. It lies within $27 \mathrm{deg} 45^{\prime}$ to $27 \mathrm{deg} 52$ ' N latitude and $85 \mathrm{deg} 16$ ' to $85 \mathrm{deg} 45$ ' E longitude. It has an altitude ranging from 1360-2732 m ASL. The Park is rich in freshwater resources with abundant biodiversity, and cultural heritage (SNNP, 2017). The park possesses a subtropical to warm temperate with average maximum and minimum temperature of $19.9 \mathrm{deg} \mathrm{C}$ and $11.15 \mathrm{deg}$ respectively with the mean annual precipitation of 236.5 mm (Climatic data from 1985 to 2017 AD, Department of Hydrology and Meteorology/ DHM).

The mountainous topography of SNNP with steep slopes of $>30 \%$ uses a pattern that constitutes $74.45 \%$ forest, $20.45 \%$ shrub land, $3.22 \%$ grassland, $1.80 \%$ cultivated area, and $0.055 \%$ other features (SNNP, 2017). Different forest types are present under different altitudes of the Park; Lower Mixed Hardwood, Chir pine Forest, Oak Forest, and Upper Mixed Hardwood Forest (Amatya, 1993). The major tree species are Schimawallichii , Alnusnepalensis ,Castronopsis spp., Myricaesculanata, Madhucaindica ,Pinusroxburghii , Pyruspashia , Aesculus sp, Acer sp., Salix sp., Lithocapus sp, Ilex dipyrena, etc.

\subsection{Sampling Sites}

We identified five representative study sites across the national park. The sampling blocks were Sundarijal, Shivapuri, Gurjebhanjyang, Nagarjun, and Manichud areas within the SNNP. Each site was sampled in three elevation transects based on forest type; lower transect occurred between $1500 \mathrm{~m}-1700 \mathrm{~m}$, middle transect at $1800 \mathrm{~m}-1900 \mathrm{~m}$, and upper transect at $2000 \mathrm{~m}-2700 \mathrm{~m}$. In each elevation, 25 line transects each of 100 m X $5 \mathrm{~m}$ with $100 \mathrm{~m}$ inter transect distance was fixed. Four types of habitats; forest trail (FT), grassland $(\mathrm{GL})$, trails of the managed habitat $(\mathrm{MH})$ and the open trail of the forest (OT), that fall under transect were surveyed. Forest habitat is denoted as the forest with canopy coverage of more than $70 \%$ with a walking trail of $15 \mathrm{~m}$ width. Grassland habitat is an herb-dominated in the transect with sparsely located trees. Open trail habitat of the forest meant the area with no tree coverage within $15 \mathrm{~m}$ width on either side of survey transect. The open trail of managed habitat is the transect along walking trail of managed habitat with no canopy tree within $15 \mathrm{~m}$ width of the trail. Managed habitat incorporates the buffer zone area of the National Park. The area is a human settlement with cultivated lands. The major crops cultivated during spring are Mustard and coriander while mustard, buckwheat, balsam apple, and squash are in autumn.

\subsection{Pollinators' sampling}

Pollinators here mean flower-visiting and nectar-feeding insects. The transect line was fixed in walking trail of forest, open forest, and managed habitat, while in the grassland transects were drawn in the edge and the middle of the grassland with $20 \mathrm{~m}$ inter transect distance (Stanley, 2013).

The survey was performed in the spring and autumn seasons for the consecutive years 2018 and 2019. In 
each season, the pollinators were sampled for 3 consecutive days in sunny weather between 9 am to $4 \mathrm{pm}$ (Pollard and Yates, 1994). The pollinators were collected by using hand sweeping and color pans. White, Yellow, and blue color pans were used for insect sampling. During each sampling day, a transect walk of 30 minutes was done along the $100 \mathrm{~m}$ of the trail in the open trail of the forest, forest trail, and trails of the managed habitat, while in grassland the transect walk was made in the edge and the middle (Stanley, 2013). The transect walk method was used to sample butterflies (Pollard \& Yates, 1994), bumblebees (Fussell and Corbet, 1992), hoverflies, and other bees (Proesmans et al., 2019). During the walk, insect pollinators that were feeding on flowers within $2 \mathrm{~m}$ of the observer were captured, identified, and released (Sutherland, 1996). In the case of the butterfly, they were observed and identified during flight and basking within the line transect. Unidentified insect pollinators were collected in separate vials, transferred in the icebox, and brought to the lab for identifications.

Similarly, pan traps were deployed in each transect. This method aided in simultaneous sampling multiple locations, coverage of a large number of sites, and is the efficient method of bee sampling (Westphal et al., 2008; Neilsen et al., 2011). The pans were plastic bowls of about $15 \mathrm{~cm}$ diameter and painted with non-toxic three different colors; white, yellow, and blue (LeBuhn et al., 2003). Each pan was attached to a post using a metal clamp adjusting bowl the rim. The pan was filled with about $400 \mathrm{ml}$ of detergent water. Three posts were deployed in $100 \mathrm{~m}$ distance and $20 \mathrm{~m}$ apart from each other. The traps were visited for collecting the fallen insects after 24 hours and were transferred in labelled vials with $70 \%$ ethanol.

\subsection{Flower Survey}

The flower survey was carried out in the spring and autumn season during the pollinator survey in the same transect. We made five quadrates of $10 \mathrm{~m} \mathrm{X} 5 \mathrm{~m}$ in each sampling transect. For estimation of flower resource abundance, we scanned insect pollinating herbs and shrubs in each quadrate and identified genus and species levels. The cover of floral resources in each quadrate was ranked between 1-6 (Szigeti et al., 2016). Rank 1 indicates very scarce, 2 for scarce, 3 for more or less scarce, 4 for more or less abundance, 5 for abundance, and 6 indicates extremely abundance. The flower resource abundance for each sampling transect was calculated as FLOWER $=\sum_{i=1}^{n} \mathrm{t} \operatorname{taxon}_{i}(t=$ mean of the rank of flowering plant of each transect $) . \backslash n \mathbf{2 . 5}$ Identification of Insect Pollinators

All the insect pollinators were identified to species level in the laboratory using relevant keys from adjacent regions. Bingham, 1897; Tadauchi \& Matsumura, 2007; Williams et al., 2010; Imran et al., 2016; Aslam et al., 2017; Ngat et al., 2017, and Kumari et al., 2018 for bee specimens. Brunetti, 1923; Ghorpade, 1994, 2016; Claussen \& Weipert, 2003; Subhan, 2016; Sengupta et al., 2017; Hassan et al., 2019, 2020; Sankararaman et al., 2020 for hoverflies and Smith, 2011 for butterflies specimen's identification.

\subsection{Statistical analysis}

For each habitat type and season, we decided the cumulative species richness and species abundance across all samplings and assembled the community matrix. Pollinator's richness and abundance were compared between different habitats and seasons, using linear mixed-effect models with habitats and seasons as predictor variables and pollinators as response variables. The statistical analysis was performed in $\mathrm{R}$, version 4.0.3. Tukey's test was carried out to find significance.

PAST. Paleontological Statistics (Hammer et al., 2001) Version 3.17 computed the diversity indices. Random matrices with two samples are generated, each with the same row and column totals as in the original data matrix which provided the significance of diversity between groups.

Pollinator's community compositions of different habitats (FT, GL, OT, MH) were analyzed by Non-metric Multidimensional Scaling (NMDS) of the abundance data employing the function meta MDS which is incorporated in the statistical package Vegan (Oksanen et al., 2013) and NMDS result with sample plots of different abundance scores was fitted with different habitats using the package 'ggplot2' (Wickham, 2016).

NMDS was followed by statistical analyses: Adonis (Permutational Multivariate Analysis of variance), ANOSIM (Analysis of similarities), and SIMPER (Similarity Percentage Analysis). 
Adonis was carried out following NMDS to analyze statistically if the pollinator community differs between the habitats. It provides the p-value to determine the statistical significance. ANOSIM, on the other hand, was used to determine if the differences of pollinator's community between the habitats are significant. In addition to the significant difference tests, Simper analyses were used to identify those species that contributed most to the observed pollinator's community differences (Clarke \& Gorley, 2001).

To find relations between the environmental variables and the species composition, ordinations were performed on insect pollinators. For the pollinator community, a detrended correspondence analysis (DCA) was carried out to decide whether unimodal or linear ordination methods were appropriate (LepVs \& VSmilauer, 2003). Based on this data, a redundancy analysis (RDA) was carried. Environmental variables were backward selected $(\mathrm{p}<0.05)$ using the 'ANOVA'. A Monte Carlo permutation test with 999 iterations was used to assess the significance of the ordination.

NMDS, RDA, and all of the three procedures (Adonis, ANOSIM, and SIMPER) were carried out in software R 4.0.3 using the "vegan" package (Oksanen et al., 2013).

Venn diagrams showing the species sharing between the habitats were performed in $\mathrm{R}$ by using the "Venn Diagram" package employing the function draw. quad. venn.

\section{RESULTS}

\section{1 Insect Pollinators in Shivapuri-Nagarjun National Park}

A total of 8720 insect pollinators (Supplementary 1) were identified from both pan (1339) and sweeping net (7381). The butterfly with the most dominant species (48.5\%) followed by a bee $(29.9 \%)$ and hoverfly $(21.5 \%)$. Over 60 flower herbs and shrubs were recorded from both sampling seasons in both years (Supplementary 2). The abundance of floral resources varied between habitats, elevation, and seasons (Supplementary 3).

\section{2 Abundance and Species richness of insect pollinators in different habitats}

Species richness and abundances were higher in open trails than in other habitats (Figure 2). There is a significant difference in species richness and abundance among habitats (Table 1, Tukey's test, $\mathrm{P}<0.05$ ).

\subsection{Analysis of Diversity and Richness of Pollinators Communities}

Diversity indices (Species richness, Shannon index) show that the open trail is comparatively more diverse, followed by the managed habitat (Table 2). The distribution of the pollinator species was much even in the open trail followed by Grassland. The species richness and Shannon Index is significant $(\mathrm{t}-$ test, $\mathrm{p}<0.05)$ in all of the habitats types. Similarly, similar evenness is observed in Forest trails and Grassland.

The highest number of species was found in the open trail (158), followed by the managed habitat (124), forest trail (103), and grassland (92). 61 species were common in all of the habitats, while the number of species exclusively found in one of the habitats was 12 for OT, 6 for FT, and 3 for MH (Figure 3). While comparing two types of habitats, the High number of habitats sharing of species was found between Open trail and Grassland (121) followed by Grassland and Forest trail (97), Managed habitat and Open Trail (82), and Grassland and Open Trail (68).

\subsection{Analysis of the Community Composition of Insect Pollinators}

The distance matrix of Bray-Curtis dissimilarity was calculated in $\mathrm{R}$ to plot non-metric multidimensional scaling (NMDS) to analyze Insect pollinator communities in four studied habitats (forest trial, grassland, managed habitat, and open trial). A stress value of 0.15 cleared convergence of NMDS ordination. Vector fitting of environmental variables showed that elevation, humidity, atmospheric temperature, and flower resource abundance were significant (Table 3; Figure 4). Flower possessed the significantly high NMDS1 score value of $0.615\left(\mathrm{P}<0.001, \mathrm{R}^{2}=0.63\right.$, Table 3$)$. Elevation and humidity were significantly negative with NMDS1 score values $-0.508\left(\mathrm{P}=0.009, \mathrm{R}^{2}=0.67\right)$ and $-1.00(\mathrm{P}=0.036, \mathrm{R} 2=0.05)$ respectively. The highest compositional abundances of species were found associated with the flower which was at lower elevation 
(Positive end of NMDS1). Similarly, high species compositional abundance was seen in the managed habitat and open trail (Positive end of NMDS1) which were again at low elevation.

Pollinators composition in four habitats are significantly different (Adonis, $\mathrm{p}<0.001$ ) with a significantly strong strength (ANOSIM, $\mathrm{R}=0.6164, \mathrm{p}<0.001$ ). Simper analysis showed that Xylocopa tenuiscapa (0.7036), Danaus genutia (0.6975), andPelopidas agna (0.6851) were three species for different compositions between Forest trail and Managed habitat. Similarly, Ceratina denticeps (0.7043), Xylocopa tenuiscapa (0.6930),Graphium sarpedon (0.6873) were three species for the difference in composition between Forest trail and Open trail. Further,Syritta orientalis (0.7019), Eoseristalis himalayensis(0.6942), Lasioglossum albipes (0.6864) were three species to contribute to the difference in the composition between forest trail and grassland. In managed habitat and open trail Andrena kathmanduensis (0.7034), Neptis hylas (0.6983), and Andrena gorkhana (0.6931) were three species to alter the pollinator's composition while Elaphropoda impatiens (0.7048), Lethe verma (0.6977) and Precis iphita (0.6909) in managed habitat and grassland. In the open trail and grassland Eristalinus taeniops (0.7007), Pieris brassica (0.6950), and Graphium sarpedon (0.6834) were three species indifferent in the composition.

\subsection{RDA analysis}

The DCA of the insect pollinator community projected a gradient length of 2.4 indicating RDA was the appropriate ordination method. Environmental factors; Elevation and flower resource abundance was found to be the significantly associated environmental factor for the pollinators (ANOVA, $\mathrm{p}<0.05$ ) (Table 4) The relation of the top 15 most abundant pollinators 9 five from each group) with these significant environmental variables are shown in RDA (Figure 5). Two canonical axes of RDA analysis explained the variance by 12.828 $\%$ in the pollinator-environmental interaction where the first axis and second axis accounted for $2.118 \%$ and $10.71 \%$ of the variance respectively. Managed habitat types represented the higher abundance of flowers associated with the high number of Apis cerana andApis mellifera. On the other hand, Pieris canidia was found associated with both open trail and grassland and Vanessa cardui in a managed habitat. Bombus eximius, Bombus flavescens, Eristalis tenax, and Ypthima baldus were more associated with the forest trail which was relatively humid area. Likewise, Melanostoma univittatum and Episyrphus viridaureus were associated with the open trail whereasEpisyrphus balteatus was close to grassland and managed habitat.

\section{DISCUSSION}

\subsection{Species richness and abundance of pollinators in different habitats}

Habitat types influence the species richness and abundance of insect pollinators. They are the highest in the open trail of the forest. In our study, species richness and abundance seem to have a direct relation to flower abundance. The abundance of flowers plays an important role in all flower visitors (Sjödin et al., 2008). The open trail of forest harbor, a comparatively thick layer of herbs and shrubs with varieties of wildflowers that suffice pollinators with nectar and pollen source. The quality and quantity of nectar and pollen matter a lot for the pollinators (Hicks et al., 2016). Trails of open forest were densely proliferated and covered by Ageratin aadenophora along with other wild herbs providing good resource plate form, especially for hoverflies and bees. Furthermore, weeds like Ranunculus repens and Trifolium repens were comparatively more abundant in the open trails. These flowers were preferred by bees and butterflies (Hicks et al., 2016; Chaguthi \& Dyola, 2019). These plants can provide nectar and pollen to these insects (Erbar \& Leins, 2013; Master \& Emery, 2015). Adult, hoverflies require high energy for hovering flight that could be obtained from the local landscape with abundant flowers (Haslett, 1989; Meyer et al., 2009; Proesmans et al., 2019). In contrast, scanty flower resources also account for the decline in pollinator species richness and abundance in forest trails with canopy. Canopy cover increases shade in the understory herb and shrub of the forest lowering flower blooms and limiting pollinator's movement (Proesmans et al., 2019). Sampled areas of the managed habitat in SNNP were open and inhabited by humans and disturbed by some human activities. Some previous study also shows that diversity of butterfly is negatively influenced by this factor of human disturbances (Kambach et al., 2013).

\subsection{Diversity and habitat sharing between pollinators}


Among all pollinators, 61 species (Figure 3) were common in all the studied habitats which show the heterogeneous habitat choice of wild bees and wider temporal range of activities of flies (Willcox et al., 2019). Hoverflies feed on varieties of food resources in different stages of life. For instance, the larva of some hoverfly develops in a close canopy while adults of the same fly hover in open flower-rich biotopes (Gittings et al., 2006). Furthermore, the abundance of hoverflies increases with proximity to the forest (Laura Moquet et al., 2018). Likewise, many bee groups require different habitats for nesting and foraging (Franzén et al., 2009) and also different spatial foraging distances made by bees like Bombus spp. and Xylocopa spp. (Greenleaf et al., 2007). This could be a probable reason for the presence of some bees group in all habitats. Butterflies too show a different kind of preference of habitats in their life cycles (Janz, 2005). Females dwell in grassland for oviposition while foraging in flower-rich habitats (Evan et al., 2020). In contrast, some pollinators are confined to only one kind of habitat. For an instant, Vollucella trifasciata and Bachha maculata were recorded from forest habitats only. This result can be linked with the findings of Coe, 1964.

\subsection{Analysis of the community composition of Insect pollinators}

The measured environmental variables (Elevation, humidity, air temperature, and flower resource abundance) are found to have a significant association with the pollinator's community. Species abundance of pollinators was concentrated in the managed habitat and open trails which were open to the high amount of solar exposer. Activities of the insect pollinators are also highly influenced by such sun exposures (McKinney \& Goodell, 2010; Sydenham et al., 2016). Similarly, flower resource abundance was the next positive influencing factor for insect pollinators. The mixture of wildflowers could be a good attraction for all these pollinators as this kind of relation of a different group was also reported in the previous study (Carreck \& Williams, 2002).

The complex environmental gradient of high altitude affects the abundance of different taxa of pollinators (Warren et al., 1988). As expected, with the elevation, the abundance of pollinators declined. The reason could be either decreasing of bee and fly attracted flowers or their limited number in higher altitude (Arnold et al., 2009). The plant communities at the high altitude limit the vascular plant and availability of insect pollinators (Mani, 1962). The atmospheric temperature and flower resource abundance have a negative correlation with elevation. Temperature is an important factor for defining the plant composition at higher altitudes (Subedi et al., 2020) and hence alters pollinator abundance. Only a few species of hoverflies that don't have specific food choices (Kearns, 1992) and big size bees, for instance, Bombus species that can thermoregulate and forage at low temperature were found in the highest altitude of our study area.

\section{RDA}

Among Hymenoptera, Apis cerana and A. mellifera were mainly determined by the flower abundance of the Buffer zone whileBombus eximius and B. flavescens were associated with humid forest. The explanation for the Apis spp. could be their preference on floral resources near the nesting area like small size bees (Vulliamy et al., 2006; Gathmann \& Tscharntke, 2002) so that they could gather maximum nectar to support the large bee colony (Potts et al., 2003). Large body-sized bees like Bombus spp. could travel away from the nesting area for foraging (Greenleaf et al., 2007) and humid areas to avoid hotter day temperatures (Willmer, 1983).Aglais caschmirensis is the most abundant and frequently seen butterfly in all kinds of habitats (Irungbam et al., 2017). This could be the reason for its presence in the forest as well as managed habitat in our study area. Similarly, the association of Episyrphus balteatus in the human habitat indicates the preference for vegetables such as coriander, buckwheat (Pinheiro et al., 2015) as their host plant. The maximum areas of human habitat were cultivated land.

\section{CONCLUSIONS}

We studied Insect pollinator community structure in different habitats of SNNP Nepal. Habitat and elevation played a significant role in the species abundance, species richness, and community structure. Insect pollinators were strongly associated with flower resource abundance which was highly recorded in an open trial. Shannon Index and evenness were high in open trial and dominance was found similar in managed habitat and grassland. Conservation of plant diversity in the walking trials of SNNP is important to conserve the 
community structure of insect pollinators.

\section{ACKNOWLEDGMENTS}

This research was funded by University Grants Commission, Nepal (Award No. Ph.D./74_75/S\&T-17). We thank Professor Dr. Vasant Kumar Thapa, Professor Dr. Bhaiya Khanal (Natural History Museum, Nepal), and Mr. Muhammad Asghar Hassan (China Agricultural University, Beijing, China) for the identification of pollinators. The first author is grateful to Mr. Bishnu Maharjan for guiding to prepare a map in Arc GIS. The first author also thanks all the students who supported in fieldwork. The first author is also grateful to the Department of National Parks and Wildlife Conservation, Nepal for providing permission for the collection of insects.

\section{CONFLICT OF INTEREST}

The authors declare that they have no conflict of interest.

\section{AUTHOR CONTRIBUTIONS}

Urmila Dyola: Conceptualization ( lead); Data Curation ( lead); Investigation ( lead); Writing - Original draft (lead); Funding acquisition ( Lead);Writing - review and editing (lead); Formal analysis ( lead); Investigation ( lead), Chitra Bahadur Baniya:Conceptualization ( Equal); Data Curation ( Equal); Investigation ( Equal); Writing original- draft ( Supporting); Formal analysis ( lead); Supervision (Equal), Puspha Raj Acharya: Conceptualization ( Equal); Writing - original draft ( Equal);Writing - review and editing (Equal); Supervision (Equal), Pradip Subedi: Data Curation ( Supporting); Investigation ( Supporting);Formal analysis ( Equal),Anjeela Pandey: Writing - original draft ( Supporting); Investigation ( Supporting), Kumar Sapkota: Conceptualization (lead); Data Curation ( Equal); Writing - original draft ( Equal);Writing - review and editing (Equal); Investigation ( lead); Supervision (Lead).

\section{Data accessibility statement}

The data associated with this manuscript are available at:

DOI https://doi.org/10.5061/dryad.9zw3r22g1

\section{REFERENCES}

Amatya, D., 1993. Forest Vegetation Analysis. Development Project, GCP/NEP/048/NOR. Kathmandu: His Majesty's Government of Nepal and Food and Agriculture Organisation of the United Nations and possible ecological implications. Braz J Biol. 64: 563-568.

Arnold, S. E., Le Comber, C. S., Chittka, L. 2009. Flower color phenology in European grassland and woodland habitats, through the eyes of pollinators. Israel Journal of Plant Sciences . 57, 211-230.

Aslam, S., Rafi, M. A., Zia, A. 2017. Non-Apis bees of family Apidae (Hymenoptera) from Potohar region of Pakistan. Journal of Entomology and Zoology Studies . 5, 6-12.

Bashir, M. A., Saeed, S., Sajjad, A., Khan, K. A., Ghramh, H. A., Shehzad, M. A., Ansari, M. J. 2019. Insect pollinator diversity in four forested ecosystems of southern Punjab, Pakistan. Saudi journal of biological sciences . 26(7), 1835-1842.

Bingham, C. T. 1897. The Fauna of British India, Including Ceylon and Burma. Hymenoptera-Vol. 1. Wasps and Bees.https://doi.org/10.5962/bhl.title.100738.

Bodlah, I., Amjad, M., Bodlah, M.A. and Qayyum, A., 2016. First record of two genera of Anthophorini and one genus of Melectini (Apinae: Apidae: Hymenoptera) from Pothwar Punjab, Pakistan. Journal of Entomology and Zoology Studies . 4:1031-1035.

Brunetti, E. 1923. Pipunculidae, Syrphidae, Conopidae, Oestridae. Diptera. Vol. 3, xi +424 pp., 6 pis. In [Shipley, A. E.] (Eds.), The Fauna of British India, including Ceylon and Burma. Taylor and Francis, London 
Cameron, S.A., Lozier, J.D., Strange, J.P., Koch, J.B., Cordes, N., Solter, L.F. and Griswold, T.L., 2011. Patterns of widespread decline in North American bumble bees. Proceedings of the National Academy of Sciences , 108 (2), pp.662-667.

Carreck, N.L. and Williams, I.H., 2002. Food for insect pollinators on farmland: insect visits to flowers of annual seed mixtures. Journal of Insect Conservation , 6 (1), pp.13-23.

Carvalheiro, L.G., Kunin, W.E., Keil, P., Aguirre-Gutierrez, J., Ellis, W.N., Fox, R., Groom, Q., Hennekens, S., Van Landuyt, W., Maes, D. and Van de Meutter, F., 2013. Species richness declines and biotic homogenisation have slowed down for NW-European pollinators and plants. Ecology letters, 16 (7), pp.870-878.

Chaguthi, G. and Dyola, U., 2018. Insect Visitors of White Clover (Trifolium Repens L) and Their Relation With Environmental Variables in the Premises of Bhaktapur Multiple Campus, Nepal. Journal of Institute of Science and Technology, 22 (2), pp.86-91.

Clarke, K.R. and Gorley, R.N., 2001. Primer V5 (Plymouth routines in multivariate ecological research): user manual/tutorial . Primer-e.

Claussen, C.J. and Weipert, J., 2003. Zur Schwebfliegenfauna Nepals (Insecta: Diptera: Syrphidae) unter besonderer Berucksichtigung Westnepals. Biodiversitat und Naturausstattung im Himalaya. Verein der Freunde und Forderer des Naturkundemuseums Erfurt ev, Erfurt, pp.343-380.

Coe, R.L. 1964. Diptera from Nepal. Bulletin of the British Museum of Natural History, Entomology . 15, $255-290$.

Corbet, S.A., Williams, I.H. and Osborne, J.L., 1991. Bees and the pollination of crops and wild flowers in the European Community. Bee world , 72 (2), pp.47-59.

De Groot, R.S., Alkemade, R., Braat, L., Hein, L. and Willemen, L., 2010. Challenges in integrating the concept of ecosystem services and values in landscape planning, management and decision making. Ecological complexity, 7 (3), pp.260-272.

Dirzo, R., Young, H.S., Galetti, M., Ceballos, G., Isaac, N.J. and Collen, B., 2014. Defaunation in the Anthropocene. science, 345 (6195), pp.401-406.

Erbar, C. and Leins, P., 2013. Nectar production in the pollen flower of Anemone nemorosa in comparison with other Ranunculaceae and Magnolia (Magnoliaceae). Organisms Diversity E Evolution , 13 (3), pp.287300.

Evans, L.C., Sibly, R.M., Thorbek, P., Sims, I., Oliver, T.H. and Walters, R.J., 2020. The importance of including habitat-specific behaviour in models of butterfly movement. Oecologia , 193 (2), pp.249-259.

Everaars, J., Strohbach, M.W., Gruber, B. and Dormann, C.F., 2011. Microsite conditions dominate habitat selection of the red mason bee (Osmia bicornis, Hymenoptera: Megachilidae) in an urban environment: A case study from Leipzig, Germany. Landscape and Urban Planning, 103 (1), pp.15-23.

Fitzpatrick, U., Murray, T.E., Paxton, R.J., Breen, J., Cotton, D., Santorum, V. and Brown, M.J., 2007. Rarity and decline in bumblebees-a test of causes and correlates in the Irish fauna. Biological conservation , 136 (2), pp.185-194.

Franzen, M., Larsson, M. and Nilsson, S.G., 2009. Small local population sizes and high habitat patch fidelity in a specialised solitary bee. Journal of Insect Conservation, 13 (1), pp.89-95.

Fussell, M. and Corbet, S.A., 1992. Flower usage by bumble-bees: a basis for forage plant management. Journal of Applied Ecology, pp.451-465.

Gathmann, A. and Tscharntke, T., 2002. Foraging ranges of solitary bees. Journal of animal ecology , 71 (5), pp.757-764. 
Ghorpade, K. 1994. Diagnostic keys to new and known genera and species of Indian subcontinent Syrphini (Diptera: Syrphidae). Colemania: Insect Biosystematics. 3, 1-15.

Ghorpade, K. 2016. Indian subcontinent species of Syritta Le Peletier \& Serville Diagnostic characters of eight species.

Ghorpade, K., 1994. Diagnostic keys to new and known genera and species of Indian subcontinent Syrphini (Diptera: Syrphidae). Colemania: Insect Biosystematics , 3 , pp.1-15.

Gilbert, L.E., 1972. Pollen feeding and reproductive biology of Heliconius butterflies. Proceedings of the National Academy of Sciences , 69 (6), pp.1403-1407.

Gill, R.J., Baldock, K.C., Brown, M.J., Cresswell, J.E., Dicks, L.V., Fountain, M.T., Garratt, M.P., Gough, L.A., Heard, M.S., Holland, J.M. and Ollerton, J., 2016. Protecting an ecosystem service: approaches to understanding and mitigating threats to wild insect pollinators. Advances in ecological research , 54 , pp.135-206.

Gittings, T., O'Halloran, J., Kelly, T. and Giller, P.S., 2006. The contribution of open spaces to the maintenance of hoverfly (Diptera, Syrphidae) biodiversity in Irish plantation forests. Forest ecology and management, 237 (1-3), pp.290-300.

Greenleaf, S.S., Williams, N.M., Winfree, R. and Kremen, C., 2007. Bee foraging ranges and their relationship to body size. Oecologia , 153 (3), pp.589-596.

Hammer, O., Harper, D.A. and Ryan, P.D., 2001. PAST: Paleontological statistics software package for education and data analysis. Palaeontologia electronica , 4 (1), p.9.

Haslett, J.R., 1989. Adult feeding by holometabolous insects: pollen and nectar as complementary nutrient sources for Rhingia campestris (Diptera: Syrphidae). Oecologia , 81 (3), pp.361-363.

Hassan, M. A., Bodlah, I., Aihetasham, A., Bodlah, M. A., Hussain, K. 2019 First Record of Baccha maculata Walker, 1852 (Diptera: Syrphidae) from the Pothwar Punjab, Pakistan. Punjab University Journal of Zoology . 34, 133-135.

http://dx.doi.org/10.1016/j.landurbplan.2011.05.008.

Hassan, M.A., Bodlah, I., Ahmad, M., Kayani, A.R. and Mahmood, K., 2020. First record of the genus Graptomyza Wiedemann, 1830 (Diptera: Syrphidae) from Pakistan. The Journal of Animal and Plant Sciences, 30 (2), pp.512-516.

Herrera, C.M., 1987. Components of pollinator" quality": comparative analysis of a diverse insect assemblage. Oikos, pp.79-90.

Hicks, D.M., Ouvrard, P., Baldock, K.C., Baude, M., Goddard, M.A., Kunin, W.E., Mitschunas, N., Memmott, J., Morse, H., Nikolitsi, M. and Osgathorpe, L.M., 2016. Food for pollinators: quantifying the nectar and pollen resources of urban flower meadows. PloS one, 11 (6), p.e0158117.

Hudewenz, A., Klein, A.M., Scherber, C., Stanke, L., Tscharntke, T., Vogel, A., Weigelt, A., Weisser, W.W. and Ebeling, A., 2012. Herbivore and pollinator responses to grassland management intensity along experimental changes in plant species richness. Biological Conservation, 150 (1), pp.42-52.

Irungbam, J.S., Huidrom, H. and Soibam, B.S., 2017. Range extension of the Indian Tortoiseshell Aglais caschmirensis aesis (Fruhstorfer, 1912)(Lepidoptera: Nymphalidae) into the hills of Manipur, India. Journal of threatened taxa , 9 (10), pp.10860-10864.

Janz, N., 2005. The relationship between habitat selection and preference for adult and larval food resources in the polyphagous butterfly Vanessa cardui (Lepidoptera: Nymphalidae). Journal of Insect Behavior , 18 (6), pp.767-780. 
Jauker, F., Diekoetter, T., Schwarzbach, F. and Wolters, V., 2009. Pollinator dispersal in an agricultural matrix: opposing responses of wild bees and hoverflies to landscape structure and distance from main habitat. Landscape Ecology, 24 (4), pp.547-555.

Jennersten, O., 1984. Flower visitation and pollination efficiency of some North European butterflies. Oecologia , 63 (1), pp.80-89.

Kambach, S., Guerra, F., Beck, S.G., Hensen, I. and Schleuning, M., 2013. Human-induced disturbance alters pollinator communities in tropical mountain forests. Diversity , 5 (1), pp.1-14.

Kearns, C.A., 1992. Anthophilous fly distribution across an elevation gradient. American Midland Naturalist , pp.172-182.

Kearns, C.A., Inouye, D.W. and Waser, N.M., 1998. Endangered mutualisms: the conservation of plantpollinator interactions. Annual review of ecology and systematics , 29 (1), pp.83-112.

Kevan, P.G., Clark, E.A. and Thomas, V.G., 1990. Insect pollinators and sustainable agriculture. American Journal of Alternative Agriculture, 5 (1), pp.13-22.

Kovacs-Hostyanszki, A., Espindola, A., Vanbergen, A.J., Settele, J., Kremen, C. and Dicks, L.V., 2017. Ecological intensification to mitigate impacts of conventional intensive land use on pollinators and pollination. Ecology Letters , 20 (5), pp.673-689.

Kremen, C., 2008. Crop pollination services from wild bees. Bee pollination in agricultural ecosystems , pp.10-26.

Kuhsel, S. and Bluthgen, N., 2015. High diversity stabilizes the thermal resilience of pollinator communities in intensively managed grasslands. Nature communications , 6 (1), pp.1-10.

Kumari, P., Kumar, N.R., Sidhu, A.K. and Chandra, K., 2018. Taxonomical and behavioural studies on Megachile conjuncta (Fabricius)(Hymenoptera: Megachilidae: Cressoniella).

Larson, B.M.H., Kevan, P.G. and Inouye, D.W., 2001. Flies and flowers: taxonomic diversity of anthophiles and pollinators. The Canadian Entomologist, 133 (4), pp.439-465.

LeBuhn, G., Griswold, T., Minckley, R., Droege, S., Roulston, T.A., Cane, J., Parker, F., Buchmann, S., Tepedino, V., Williams, N. and Kremen, C., 2003. A standardized method for monitoring bee populationsthe bee inventory (BI) plot. Accessed , 16, p.15.

Lepš, J. and Šmilauer, P., 2003. Multivariate analysis of ecological data using CANOCO . Cambridge university press.

Lieftinck, M.A., 1966. Notes on some anthophorine bees, mainly from the Old World (Apoidea). Tijdschrift voor Entomologie, 109 (6), pp.125-161.

Losey, J.E. and Vaughan, M., 2006. The economic value of ecological services provided by insects. Bioscience , 56 (4), pp.311-323.

Mani, M. S. 1962. Introduction to high altitude Entomology insect life above the timber-line in the northwest Himalaya (No. 595.70954 M3).

Masters, J.A. and Emery, S.M., 2015. The showy invasive plant Ranunculus ficaria facilitates pollinator activity, pollen deposition, but not always seed production for two native spring ephemeral plants. Biological Invasions , 17 (8), pp.2329-2337.

McKinney, A.M. and Goodell, K., 2010. Shading by invasive shrub reduces seed production and pollinator services in a native herb. Biological Invasions , 12 (8), pp.2751-2763.

Meyer, B., Jauker, F. and Steffan-Dewenter, I., 2009. Contrasting resource-dependent responses of hoverfly richness and density to landscape structure. Basic and Applied Ecology , 10 (2), pp.178-186. 
Moquet, L., Laurent, E., Bacchetta, R. and Jacquemart, A.L., 2018. Conservation of hoverflies (Diptera, Syrphidae) requires complementary resources at the landscape and local scales. Insect Conservation and Diversity , 11 (1), pp.72-87.

Ngat, T. T., Minh, N. P., Lam, T. X., Thi, N., Lien, P. 2017. Studies of the Genus Thyreus Panzer ( Hymenoptera : Apidae : Apinae ) with Six New Records from Vietnam. 9, 227-236.

Nielsen, A., Steffan-Dewenter, I., Westphal, C., Messinger, O., Potts, S.G., Roberts, S.P., Settele, J., Szentgyörgyi, H., Vaissière, B.E., Vaitis, M. and Woyciechowski, M., 2011. Assessing bee species richness in two Mediterranean communities: importance of habitat type and sampling techniques. Ecological research , 26 (5), pp.969-983.

Oksanen, J., Blanchet, F.G., Kindt, R., Legendre, P., Minchin, P.R., O'hara, R.B., Simpson, G.L., Solymos, P., Stevens, M.H.H., Wagner, H. and Oksanen, M.J., 2013. Package 'vegan'. Community ecology package, version, 2 (9), pp.1-295.

Oliver, T., Roy, D.B., Hill, J.K., Brereton, T. and Thomas, C.D., 2010. Heterogeneous landscapes promote population stability. Ecology letters , 13 (4), pp.473-484.

Pinheiro, L.A., Torres, L.M., Raimundo, J. and Santos, S.A., 2015. Effects of pollen, sugars and honeydew on lifespan and nutrient levels of Episyrphus balteatus. BioControl , 60 (1), pp.47-57.

Pollard, E. and Yates, T.J., 1994. Monitoring butterflies for ecology and conservation: the British butterfly monitoring scheme. Springer Science \& Business Media.

Potts, S.G., Biesmeijer, J.C., Kremen, C., Neumann, P., Schweiger, O. and Kunin, W.E., 2010. Global pollinator declines: trends, impacts and drivers. Trends in ecology $\&$ evolution , 25 (6), pp.345-353.

Potts, S.G., Vulliamy, B., Dafni, A., Ne'eman, G. and Willmer, P., 2003. Linking bees and flowers: how do floral communities structure pollinator communities?. Ecology , 84 (10), pp.2628-2642.

Proesmans, W., Bonte, D., Smagghe, G., Meeus, I. and Verheyen, K., 2019. Importance of forest fragments as pollinator habitat varies with season and guild. Basic and applied ecology , 34 , pp.95-107.

Reemer, M., 2005. Saproxylic hoverflies benefit by modern forest management (Diptera: Syrphidae). Journal of insect conservation, 9 (1), pp.49-59.

Rundlöf, M., Nilsson, H. and Smith, H.G., 2008. Interacting effects of farming practice and landscape context on bumble bees. Biological conservation , 141 (2), pp.417-426.

Sankararaman, H., Daniel, J. A., Manickavasagam, S. and Pennards, G., 2020. First record of two interesting genera of hover flies (Diptera: Syrphidae) in South India. Journal of Insect Biodiversity ,14 (2), pp.54-63.

Sengupta, J., Naskar, A., Maity, A., Hazra, S., Sarkar, N.K. and Banerjee, D., 2017. Hover Flies (Diptera: Syrphidae) from Darjeeling Himalaya-A Part of Indo-Burmese Hotspot. Indian Journal of Entomology , 79 (3), pp.336-353.

Sharp, M.A., Parks, D.R. and Ehrlich, P.R., 1974. Plant resources and butterfly habitat selection. Ecology , 55 (4), pp.870-875.

Sjödin, N.E., Bengtsson, J. and Ekbom, B., 2008. The influence of grazing intensity and landscape composition on the diversity and abundance of flower-visiting insects. Journal of Applied Ecology , 45 (3), pp.763-772.

Smith, C. 2011 Illustrated checklists of Nepal's butterflies. Mujpuria Publication, Craftman Press, Bangkok, Thailand.

SNNP, 2017. Shivapuri-Nagarjun National Park and Buffer Zone, Management Plan. Kathmandu: Shivapuri-Nagarjun Park Office, Panimuhan, Kathmandu, Nepal. 
Stanley, D.A., 2013. Pollinators and Pollination in Changing Agricultural Landscapes: Investigating the Impacts of Bioenergy Crops (Doctoral dissertation, Trinity College Dublin).

Subedi, C.K., Rokaya, M.B., Munzbergova, Z., Timsina, B., Gurung, J., Chettri, N., Baniya, C.B., Ghimire, S.K. and Chaudhary, R.P., 2020. Vascular plant diversity along an elevational gradient in the Central Himalayas, western Nepal. Folia Geobotanica, 55 (2), pp.127-140.

Subhan, F. 2016. Taxonomic study of Syrphidae (Diptera) of Northern dry mountains region of Pakistan (Doctoral dissertation, The University of Agriculture, Peshawar-Pakistan).

Sutherland, W.J., 1996. 11 The twenty commonest surveying sins. Ecological Census Techniques: A Handbook, p.317.

Sydenham, M.A., Hausler, L.D., Moe, S.R. and Eldegard, K., 2016. Inter-assemblage facilitation: The functional diversity of cavity-producing beetles drives the size diversity of cavity-nesting bees. Ecology and evolution , 6 (2), pp.412-425.

Szigeti, V., Körösi, Á., Harnos, A., Nagy, J. and Kis, J., 2016, September. Comparing two methods for estimating floral resource availability for insect pollinators in semi-natural habitats. In Annales de la Société entomologique de France (NS) (Vol. 52, No. 5, pp. 289-299). Taylor \& Francis.

Tadauchi, O. and Matsumura, T., 2007. The genus Andrena collected from Nepal (Hymenoptera, Andrenidae) with redescriptions of some types of Andrena described from North India. Esakia , 47, pp.1-20.

Tiple, A.D., Deshmukh, V.P. and Dennis, R.L., 2005. Factors influencing nectar plant resource visits by butterflies on a university campus: implications for conservation. Nota lepidopterologica , 28 (3/4), p.213.

Van Swaay, C.C., Cuttelod, A., Collins, S., Maes, D., Munguira, M.L., Šašić, M., Settele, J., Verovnik, R., Verstrael, T., Warren, M. and Wiemers, M., 2010. European red list of butterflies.

Vanbergen, A.J. and Initiative, T.I.P., 2013. Threats to an ecosystem service: pressures on pollinators. Frontiers in Ecology and the Environment, 11 (5), pp.251-259.

VanEngelsdorp, D., Hayes Jr, J., Underwood, R.M. and Pettis, J., 2008. A survey of honey bee colony losses in the US, fall 2007 to spring 2008. PloS one, 3 (12), p.e4071.

Vulliamy, B., G. Potts, S. and G. Willmer, P., 2006. The effects of cattle grazing on plant-pollinator communities in a fragmented Mediterranean landscape. Oikos, 114 (3), pp.529-543.

Warren, M.S., Hill, J.K., Thomas, J.A., Asher, J., Fox, R., Huntley, B., Roy, D.B., Telfer, M.G., Jeffcoate, S., Harding, P. and Jeffcoate, G., 2001. Rapid responses of British butterflies to opposing forces of climate and habitat change. Nature, 414 (6859), pp.65-69.

Warren, S.D., Harper, K.T. and Booth, G.M., 1988. Elevational distribution of insect pollinators. American Midland Naturalist, pp.325-330.

Weibull, A.C., Bengtsson, J. and Nohlgren, E., 2000. Diversity of butterflies in the agricultural landscape: the role of farming system and landscape heterogeneity. Ecography , 23 (6), pp.743-750.

Westphal, C., Bommarco, R., Carré, G., Lamborn, E., Morison, N., Petanidou, T., Potts, S.G., Roberts, S.P., Szentgyörgyi, H., Tscheulin, T. and Vaissière, B.E., 2008. Measuring bee diversity in different European habitats and biogeographical regions. Ecological monographs, 78 (4), pp.653-671.

Wickham, H., Chang, W. and Wickham, M.H., 2016. Package 'ggplot2'. Create Elegant Data Visualisations Using the Grammar of Graphics. Version, 2 (1), pp.1-189.

Widhiono, I., Sudiana, E. and SUCIANTO, E.T., 2016. Insect pollinator diversity along a habitat quality gradient on Mount Slamet, Central Java, Indonesia. Biodiversitas Journal of Biological Diversity, 17 (2). 
Willcox, B.K., Howlett, B.G., Robson, A.J., Cutting, B., Evans, L., Jesson, L., Kirkland, L., JeanMeyzonnier, M., Potdevin, V., Saunders, M.E. and Rader, R., 2019. Evaluating the taxa that provide shared pollination services across multiple crops and regions. Scientific reports, 9 (1), pp.1-10.

Williams, P.H., Ito, M., Matsumura, T. and Kudo, I., 2010. The bumblebees of the Nepal Himalaya (Hymenoptera: Apidae). Insecta matsumurana. New series: journal of the Faculty of Agriculture Hokkaido University, series entomology. , 66 , pp.115-151.

Willmer, P.G., 1983. Thermal constraints on activity patterns in nectar-feeding insects. Ecological Entomology , 8 (4), pp.455-469.

Wojcik, V., 2021. Pollinators: Their Evolution, Ecology, Management, and Conservation. In Arthropods . IntechOpen.

\section{Hosted file}

Figure. docx available at https://authorea.com/users/439683/articles/540562-insect-pollinators-community-structure-in-different-habitats-of-shivapuri-nagarjun-national-park-nepal 